\title{
THERMAL PROPERTIES OF HYDROFLUORIDES
}

\author{
A. V. Nikolaev, A. A. Opalovsky, V. E. Fedorov and \\ T. D. Fedotova
}

Institute of Inorganic Chemistry, Siberian Department of the Academy of Sciences of the U.S.S.R., Novosibirsk, U.S.S.R.

(Received November 22, 1972)

\begin{abstract}
Data are presented on the properties of alkali metal and alkaline earth hydrofluorides. Melting, thermal decomposition and interaction of hydrofluorides with various classes of inorganic substances are discussed. Some regularities of changes in thermal properties within the sequences of the above hydrofluorides are established. Future directions of research in this field are outlined.
\end{abstract}

In view of the increasing interest in the thermal properties of hydrofluorides [1], it appears timely to summarize some results and outline the future prospects in this field. In the present paper, we attempt to survey the data available, aiming at critical analysis, systematization and generalization.

When hydrofluorides are heated, different types of behaviour are observed: some hydrofluorides melt congruously, others melt incongruently, while a number of hydrofluorides, including e.g. lithium and sodium bifluorides and alkaline earth hydrofluorides, decompose before melting.

Data on the melting temperature of hydrofluorides and on the properties of their melts, of general interest for the characterization of this class of compounds, are also important for practice, since they define technological conditions in many important industrial processes, such as the production of fluorine, hydrofluoric acid and many other fluorine compounds.

The first determined melting points of hydrofluorides [2-5] were mostly erroneous, due to various reasons connected with impurities in the investigated compounds, the experimental techniques, etc. Later, more exact data for alkali metal and ammonium hydrofluorides were obtained by studying the melt diagrams of the systems HF - MF [6-11]. Experimental data indicate that of the above hydrofluorides only $\mathrm{NaF} \cdot 3 \mathrm{HF}$ melts incongruously. Later, however, it was assumed that the potassium hydrofluorides $\mathrm{KF} \cdot 2.5 \mathrm{HF}$ and $\mathrm{KF} \cdot 3 \mathrm{HF}$ also melt incongruously [12].

In the series of alkali metal and ammonium hydrofluorides, there is a tendency for the melting point to decrease with the increase of the number of attached HF molecules.

For alkali metal hydrofluorides of similar composition, the melting point decreases with increase of the ionic radius of the cation (Table 1). 
The melts of many hydrofluorides have found practical applications, and a knowledge of their properties is therefore of substantial interest. Since the most frequent use is made of potassium and ammonium hydrofluorides, the properties of these melts have been studied in more detail.

Table 1

Melting points of hydrofluorides

\begin{tabular}{l|c|c|c}
\hline \multicolumn{1}{c|}{ Compound } & $\begin{array}{c}\text { Melting point } \\
{ }^{\circ} \mathrm{C}\end{array}$ & Compound & $\begin{array}{c}\text { Melting point } \\
{ }^{\circ} \mathrm{C}\end{array}$ \\
\hline $\mathrm{NaF} \cdot 3 \mathrm{HF}$ & 60.5 & $\mathrm{RbF} \cdot 3.5 \mathrm{HF}$ & $34-40$ \\
$\mathrm{NaF} \cdot 4 \mathrm{HF}$ & 39.8 & $\mathrm{RbF} \cdot 4.5 \mathrm{HF}$ & 23 \\
$\mathrm{KF} \cdot \mathrm{HF}$ & 238.7 & $\mathrm{NH}_{4} \mathrm{~F} \cdot \mathrm{HF}$ & 126.3 \\
$\mathrm{KF} \cdot 2 \mathrm{HF}$ & 71.7 & $\mathrm{NH}_{4} \mathrm{~F} \cdot 3 \mathrm{HF}$ & 23.4 \\
$\mathrm{KF} \cdot 2.5 \mathrm{HF}$ & 64.3 & $\mathrm{NH}_{4} \mathrm{~F} \cdot 5 \mathrm{HF}$ & -8.2 \\
$\mathrm{KF} \cdot 3 \mathrm{HF}$ & 65.8 & $\mathrm{CsF} \cdot \mathrm{HF}$ & 180.0 \\
$\mathrm{KF} \cdot 4 \mathrm{HF}$ & 72.0 & $\mathrm{CsF} \cdot 2 \mathrm{HF}$ & 50.2 \\
$\mathrm{RbF} \cdot \mathrm{HF}$ & $204-205$ & $\mathrm{CsF} \cdot 3 \mathrm{HF}$ & 32.6 \\
$\mathrm{RbF} \cdot 2 \mathrm{HF}$ & 51.7 & $\mathrm{CsF} \cdot 6 \mathrm{HF}$ & -42.3 \\
$\mathrm{RBF} \cdot 3 \mathrm{HF}$ & 45.0 & & \\
& & &
\end{tabular}

Density, viscosity and electrical conductivity of the system $\mathrm{HF}-\mathrm{KF}$ have been studied in the temperature range $80-150^{\circ}$ at hydrofluoric acid concentrations between 36 and $45 \%$. With increasing temperature, the density of the melt decreases linearly, as evidence of the ideality of the system HF - KF. The density and viscosity isotherms are S-shaped, with the horizontal portion of the curves corresponding to the formation of the hydrofluoride $\mathrm{KF} \cdot 2 \mathrm{HF}$. Conductivity values measured at 90,95 and $100^{\circ}$ increase with increasing hydrofluoric acid concentrations [13, 14].

Addition of lithium and sodium fluorides to potassium hydrofluorides markedly decreases their melting points, irrespective of the slight solubility of LiF and $\mathrm{NaF}$ in these melts $[7,15]$. The S-shape of the density and viscosity isotherms of the system HF - KF is retained when $\mathrm{LiF}, \mathrm{NaF}, \mathrm{RbF}$ and $\mathrm{CsF}$ are added $[16,17]$.

The density and viscosity of melts in the system $\mathrm{HF}-\mathrm{NH}_{4} \mathrm{~F}$ have been studied in the temperature range $20-190^{\circ}$ at $\mathrm{NH}_{3}$ contents of $15-30 \%$. With increasing temperature the density of the melts decreases the more, the higher the ammonium concentration of the melt. The viscosity of the melts decreases slightly with increasing temperature [18].

Views concerning the dissociation mechanism of ammonium hydrofluoride melts are contradictory. Semerikova and co-workers [18] estimate that ammonium hydrofluorides themselves are only slightly dissociated, but promote the dissociation of hydrofluoric acid. However, data reported in [19] lead to the conclusion that the dissociation of ammonium hydrofluorides is analogous to the dissociation of potassium hydrofluorides:

$$
\mathrm{KF} \cdot n \mathrm{HF} \rightleftharpoons \mathrm{K}^{+}+H_{n} \mathrm{~F}_{n+1}^{-} ; \mathrm{NH}_{4} \mathrm{~F} \cdot n \mathrm{HF} \rightleftharpoons \mathrm{NH}_{4}^{+}+\mathrm{H}_{n} \mathrm{~F}_{n+1}^{-} \text {. }
$$


With respect to thermal stability, a general regularity is observed within the series of hydroffuorides, namely that the thermal stability decreases with the increase in charge of the cation, with the decrease of the cation radius and with the increasing polarizing power of the cation. Hence, in general the hydrofluorides of monovalent metals are thermally more stable than hydrofluorides of bivalent metals.

The thermal stabilities of alkali metal bifluorides have been studied in greatest detail.

Among these compounds, lithium bifluoride is the least stable. Stored in air at ambient temperature, it gradually loses hydrofluoric acid and is transformed to $\mathrm{LiF}$ [20]. Extrapolation of $\mathrm{HF}$ vapour pressure data above $\mathrm{LiF} \cdot \mathrm{HF}$ in the range $36-118^{\circ}$ yields a decomposition temperature of $129.5^{\circ}$ [21]. The vapour pressure of HF above lithium bifluoride at $25^{\circ}$ is 1.89 torr. In $[21,22]$ the thermodynamic functions of the decomposition of LiF $\cdot$ HF are reported (Table 2).

Table 2

Thermodynamic functions of lithium bifluoride decomposition

\begin{tabular}{l|l}
\hline$\Delta C_{\mathrm{p}}^{\circ}, \mathrm{cal} / \mathrm{K} \cdot$ mole & $-0.35(300 \mathrm{~K}),-1.47(375 \mathrm{~K})$ \\
$\Delta S_{298}^{\circ}, \mathrm{cal} / \mathrm{K} \cdot$ mole & $16.97 \pm 0.04$ \\
$\Delta F_{298}^{\circ}, \mathrm{kcal} / \mathrm{mole}$ & $3.5 \pm 0.1$ \\
$\Delta G_{298}^{\circ}, \mathrm{kcal} / \mathrm{mole}$ & $3.55 \pm 0.04$ \\
$\Delta H, \mathrm{kcal} / \mathrm{mole}$ & $13.7 \pm 0.3(300-375 \mathrm{~K})$ \\
$\Delta H_{298}^{\circ}, \mathrm{kcal} / \mathrm{mole}$ & $13.41 \pm 0.05$
\end{tabular}

The vapour pressure of $\mathrm{HF}$ above sodium bifluoride has been measured with various methods at various temperatures, and enthalpy values have been calculated (Table 3) [23-27].

Table 3

Thermal stability of sodium bifluoride calculated from vapour pressure data

\begin{tabular}{c|c|c|c}
\hline $\begin{array}{c}\text { Tempera- } \\
\text { ture range, } \\
\circ\end{array}$ & $\begin{array}{c}\text { Temperature dependence } \\
\text { of vapour pressure }\end{array}$ & $\begin{array}{l}\Delta H_{\text {decomp. }} \\
\text { kcal/mole }\end{array}$ & Ref. \\
\hline $37-100$ & $\log p_{\text {atm }}=6.677-3940 / \mathrm{T}$ & 18.0 & {$[23]$} \\
$40-120$ & $\log p_{\operatorname{mm}}=11.19-4292 / \mathrm{T}$ & 19.6 & {$[24]$} \\
$100-250$ & $\log p_{\mathrm{mm}}=9.97-3830 / \mathrm{T}$ & 14.8 & {$[25]$} \\
$126-205$ & $\log p_{\mathrm{mm}}=9.475-3521 / \mathrm{T}$ & 17.5 & {$[26]$} \\
$157-269$ & & - & {$[27]$}
\end{tabular}

Extrapolation of vapour pressure data yields a decomposition temperature of $278^{\circ}$ for $\mathrm{NaF} \cdot \mathrm{HF}$ [25]. For the free energy of the decomposition process, the equation

$$
\Delta F=16.11 \times 10^{3}-30.17 T\left(157-269^{\circ}\right)
$$

was obtained [27]. 
Our thermogravimetric studies on a number of alkali metal bifluorides [28, 29] indicated that the decompositions of lithium and sodium bifluorides proceed in one stage, corresponding to

$$
\mathrm{MF} \cdot \mathrm{HF}(\mathrm{s}) \rightarrow \mathrm{MF}(\mathrm{s})+\mathrm{HF}(\mathrm{g})
$$

The kinetics of the decompositions were studied under both non-isothermal and isothermal conditions (Table 4).

Table 4

Kinetic parameters of lithium and sodium bifluoride decomposition processes

\begin{tabular}{|c|c|c|c|c|}
\hline \multirow[b]{2}{*}{ Compound } & \multicolumn{2}{|c|}{ Non-isothermal conditions } & \multicolumn{2}{|c|}{$\begin{array}{l}\text { Energy of activation under iso- } \\
\text { thermal conditions, } \mathrm{kcal} / \mathrm{mole}\end{array}$} \\
\hline & $\begin{array}{l}\text { tempera- } \\
\text { ture of } \\
\text { maximum } \\
\text { devel- } \\
\text { opment of } \\
\text { reaction } \\
{ }^{\circ} \mathrm{C}\end{array}$ & $\begin{array}{l}\text { energy of } \\
\text { activation, } \\
\text { kcal/mole }\end{array}$ & $\begin{array}{l}\text { calcd. from } \\
1-\alpha=e^{-k x^{n}}\end{array}$ & $\begin{array}{c}\text { calcd. from } \\
1-\sqrt[3]{1-\alpha}= \\
=k \tau\end{array}$ \\
\hline $\mathrm{LiF} \cdot \mathrm{HF}$ & 151 & $17.5 \pm 0.4$ & $14.0 \pm 0.3$ & $13.1 \pm 0.3$ \\
\hline $\mathrm{NaF} \cdot \mathrm{HF}$ & 268 & $18.3 \pm 0.4$ & $19.4 \pm 0.2$ & $21.4 \pm 0.2$ \\
\hline
\end{tabular}

The thermal stabilities of potassium, rubidium and caesium bifluorides are close to each other. The thermogravimetric study of these compounds demonstrated that the character of their thermal decompositions differs from that of ithium and sodium bifluorides, which decompose without melting. When potassium, rubidium and caesium bifluorides are heated, they first undergo polymorphous transformation and subsequently melt. On further heating, their decomposition starts. This is indicated on the thermal curve by a complex endothermic effect, pointing to stepwise release of hydrofluoric acid from the melt. This process proceeds within a rather wide temperature range. The temperature at which decomposition is completed increases from potassium to caesium [28].

Table 5

Thermodynamic functions of potassium bifuoride decomposition

\begin{tabular}{l|c|c}
\hline & $298.16 \mathrm{~K}$ & $500 \mathrm{~K}$ \\
\hline$\Delta C_{\mathrm{p}}^{\circ}, \mathrm{cal} / \mathrm{K} \cdot \mathrm{mole}$ & 0.32 & -.047 \\
$\Delta S^{\circ}, \mathrm{cal} / \mathrm{K} \cdot \mathrm{mole}$ & 32.52 & 26.17 \\
$-\Delta\left(F^{\circ}-H_{0}^{\circ}\right) / T, \mathrm{cal} / \mathrm{K} \cdot$ mole & 29.86 & 30.51 \\
$\Delta\left(H^{\circ}-H_{0}^{\circ}\right), \mathrm{kcal} / \mathrm{mole}$ & 0.791 & -2.167 \\
$\Delta F^{\circ}, \mathrm{kcal} / \mathrm{mole}$ & 11.630 & 5.278 \\
$\Delta H^{\circ}, \mathrm{kcal} / \mathrm{mole}$ & 21.324 & 18.366 \\
$\Delta H_{0}^{\circ}=20.533 \mathrm{kcal} / \mathrm{mole}$ & &
\end{tabular}


The vapour pressure of $\mathrm{HF}$ above $\mathrm{KF} \cdot \mathrm{HF}$ has been measured in the temperature range $230.5-347.5^{\circ}$ [30]. The temperature dependence of the vapour pressure of HF above $\beta$-phase KF $\cdot$ HF is given by the equation

$$
\log \mathrm{p}_{\mathrm{mm}}=8.57-4000 / T \quad\left(196-238.7^{\circ}\right)
$$

The thermodynamic functions of potassium bifluoride decomposition have been calculated (Table 5) [31].

A comparison of the standard enthalpies of alkali metal bifluoride decompositions $[22,31,32]$ indicates that the thermal stability of these compounds increases with increasing cation radius. Thermal stability data for alkali metal bifluorides correlate with the hydrogen bond strengths in these compounds.

The reaction $\mathrm{MF} \cdot \mathrm{HF} \rightleftharpoons \mathrm{MF}+\mathrm{HF}$ is kinetically readily reversible. Methods based on the formation of hydrofluorides are therefore widely used for hydrofluoric acid removal. Above all, the application of this reaction in chemical technology for the purification of fluorine, chlorine trifluoride and other fluorinecontaining gases from hydrofluoric acid contamination should be noted [33-35]. Methods for the recovery of hydrofluoric acid from stack gases have recently gained increasing importance in various branches of industry. These latter methods are based on the formation of alkali metal bifluorides in aqueous solutions. The bifluorides obtained from the solution are subsequently thermally decomposed to yield $\mathrm{HF}$.

The selection of a suitable sorbent for HF is connected with the thermal stability of the hydrofluoride formed. Potassium, rubidium and caesium bifluorides are thermally most stable. However, the decompositions of these compounds start only after their melting and proceed at rather high temperatures, causing difficulties in HF desorption and recycling of fluorides. Further, rubidium and caesium salts are rather hygroscopic. Thus, sodium fluoride is mainly used in industrial practice for hydrofluoric acid absorption. Sorption of HF is carried out at about $100^{\circ}$, and desorption at $350^{\circ}$ [36]. To increase the efficiency of absorption, the sorbent is applied in the form of $\mathrm{NaF}$ pellets obtained by thermal decomposition of pelletized sodium biffuoride $[25,36]$.

Passing now to the discussion of the thermal stabilities of alkali metal hydrofluorides corresponding to the formula MF $n \mathrm{HF}(n>1)$, it should be noted that attention has been paid mainly to potassium hydrofluorides, since these compounds are used as the electrolyte in fluorine production. The vapour pressure in the system $\mathrm{HF}-\mathrm{KF}$ has been measured by Cady [7] who constructed isobars for 50,100 and 250 torr. Later, the vapour pressure above melted $\mathrm{HF}-\mathrm{KF}$ was studied in the area of $\mathrm{KF} \cdot 2 \mathrm{HF}$ formation within the temperature range $70-$ $110^{\circ}$ [37]. Data on the system HF - KF [7] have been further utilized to establish the dependence of HF vapour pressure on the composition of the melt (from $\mathrm{KF}$ to $\mathrm{KF} \cdot 4 \mathrm{HF}$ ) at temperatures of $298-550 \mathrm{~K}$ [12].

Addition of lithium fluoride leads to a slight decrease of the HF vapour pressure above melted $\mathrm{KF}-\mathrm{HF}$ [37]. Addition of $\mathrm{NaF}$ (up to $5 \%$ ) also reduces $\mathrm{HF}$ vapour pressure. However, a further increase of the $\mathrm{NaF}$ concentration results in an in- 
crease of the vapour pressure, possibly because sodium hydrofluoride is formed in the melt [38].

Enthalpies of $\mathrm{NaF} \cdot 2 \mathrm{HF}$ decomposition have been determined [39]:

$$
\begin{aligned}
& \mathrm{NaF} \cdot 2 \mathrm{HF}(\mathrm{s}) \rightarrow \mathrm{NaF} \cdot \mathrm{HF}(\mathrm{s})+\mathrm{HF}(\mathrm{g}), \Delta H^{\circ}=10.3 \pm 0.3 \mathrm{kcal} / \mathrm{mole} \\
& \mathrm{NaF} \cdot 2 \mathrm{HF}(\mathrm{s}) \rightarrow \mathrm{NaF}(\mathrm{s})+2 \mathrm{HF}(\mathrm{g}), \Delta H^{\circ}=28.1 \pm 0.3 \mathrm{kcal} / \mathrm{mole}
\end{aligned}
$$

Very few data, and mostly of a qualitative character, are available concerning the thermal stabilities of other $\mathrm{MF} \cdot n \mathrm{HF}(n>1)$ alkali metal hydrofluorides. $\mathrm{NaF} \cdot 3 \mathrm{HF}$ and $\mathrm{NaF} \cdot 4 \mathrm{HF}$ are transformed into the bifluoride in air at ambient temperature [40]. Under the same conditions, potassium hydrofluorides are transformed into $\mathrm{KF} \cdot 2 \mathrm{HF}$, which in turn is converted into $\mathrm{KF} \cdot \mathrm{HF}$ at $150^{\circ}$ [41]. $\mathrm{RbF} \cdot 2 \mathrm{HF}$ is stable at ambient temperatures, but starts to split off noticeable amounts of $\mathrm{HF}$ at $100-110^{\circ}$ [8] and is transformed into $\mathrm{RbF} \cdot \mathrm{HF}$ at $150-190^{\circ}$ in the course of some hours [42]. According to [8], the vapour pressure of $\mathrm{HF}$ above $\mathrm{RbF} \cdot n \mathrm{HF}(n=2,3,3.5)$ is low at ambient temperature.

The thermal dissociations of ammonium hydrofluorides differ from those of alkali metal hydrofluorides insofar as the gas phase contains not only hydrofluoric acid, but also ammonia.

The thermogravimetric data indicate that ammonium bifluoride starts to decompose at $80^{\circ}$ and that the maximum reaction rate is reached at $235^{\circ}$ [43]. The composition of the gas phase above melted $\mathrm{NH}_{4} \mathrm{~F} \cdot \mathrm{HF}$ at 135 and $150^{\circ}$ is incongruous with the composition of the melt [44].

The vapour pressure above the system $\mathrm{HF}-\mathrm{NH}_{4} \mathrm{~F}$ has been measured in the temperature range $30-140^{\circ}$ at ammonia contents of $26-42 \%$. The minimum vapour pressure corresponds to the composition $\mathrm{NH}_{4} \mathrm{~F} \cdot \mathrm{HF}$. The ratio of the partial pressures of $\mathrm{HF}$ and $\mathrm{NH}_{3}$ depends on the ratio of the components, and on the temperature [45].

Table 6

Enthalpies of ammonium hydrofluoride decomposition processes

\begin{tabular}{l|l|l}
\hline \multicolumn{1}{c|}{ Process } & $\begin{array}{c}\Delta H^{\circ} \\
\mathrm{kca} / \mathrm{mole}\end{array}$ & $\begin{array}{c}\text { Refe- } \\
\text { rence }\end{array}$ \\
\hline $\mathrm{NH}_{4} \mathrm{~F} \cdot \mathrm{HF}(\mathrm{s}) \rightarrow \mathrm{NH}_{4} \mathrm{~F}(\mathrm{~s})+\mathrm{HF}(\mathrm{g})$ & 16.1 & {$[39]$} \\
$\mathrm{NH}_{4} \mathrm{~F} \cdot \mathrm{HF}(\mathrm{s}) \rightarrow \mathrm{NH}_{3}(\mathrm{~g})+2 \mathrm{HF}(\mathrm{g})$ & 51.1 & {$[46]$} \\
& 51.4 & {$[47]$} \\
$\mathrm{NH}_{4} \mathrm{~F} \cdot \mathrm{HF}(\mathrm{g}) \rightarrow \mathrm{NH}_{3}(\mathrm{~g})+2 \mathrm{HF}(\mathrm{g})$ & 51.9 & {$[39]$} \\
$\mathrm{NH}_{4} \mathrm{~F} \cdot 3 \mathrm{HF}(\mathrm{l}) \rightarrow \mathrm{NH}_{4} \mathrm{~F} \cdot \mathrm{HF}(\mathrm{s})+2 \mathrm{HF}(\mathrm{g})$ & 33.85 & {$[48]$} \\
& 17.6 & {$[39]$} \\
$\mathrm{NH}_{4} \mathrm{~F} \cdot 3 \mathrm{HF}(\mathrm{l}) \rightarrow \mathrm{NH}_{4} \mathrm{~F}(\mathrm{~s})+3 \mathrm{HF}(\mathrm{g})$ & 17.1 & {$[46]$} \\
$\mathrm{NH}_{4} \mathrm{~F} \cdot 3 \mathrm{HF}(\mathrm{l}) \rightarrow \mathrm{NH}_{3}(\mathrm{~g})+4 \mathrm{HF}(\mathrm{g})$ & 33.7 & {$[39]$} \\
& 69.5 & {$[39]$}
\end{tabular}


Measurements of the vapour pressure above $\mathrm{NH}_{4} \mathrm{~F} \cdot 3 \mathrm{HF}$ have given the relationship [11]

$$
p_{\mathrm{mm}}=-5288 / T+20.97 \quad\left(263-296.4^{\circ}\right) .
$$

Ammonium hydrofluoride decomposition enthalpies have been calculated from vapour pressure measurements and from thermochemical data (Table 6).

We have studied the thermal stabilities of a number of alkaline earth hydrofluorides thermogravimetrically $[29,49,50]$. All these compounds decompose without melting, and the majority of them are thermally unstable even at ambient temperature.

The decompositions of $\mathrm{BaF}_{2} \cdot 4.5 \mathrm{HF}$ and $\mathrm{BaF}_{2} \cdot 3 \mathrm{HF}$ proceed stepwise:

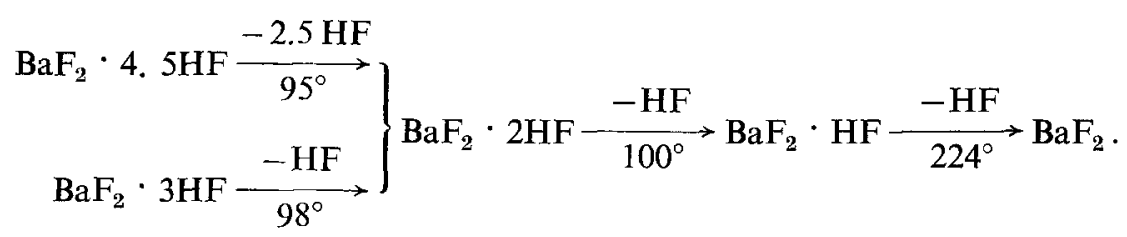

(Temperatures indicated in the equation correspond to maximum development of the reaction.)

The intermediate $\mathrm{BaF}_{2} \cdot 2 \mathrm{HF}$ was not known earlier. The decomposition of this hydrofluoride, which has been isolated, also proceeds stepwise, via $\mathrm{BaF}_{\mathbf{2}} \cdot \mathrm{HF}$, which is the most stable of all alkaline earth metal hydrofluorides. The decomposition of $\mathrm{BaF}_{2} \cdot \mathrm{HF}$ was studied under both isothermal and non-isothermal conditions.

$\mathrm{SrF}_{2} \cdot 2.5 \mathrm{HF}$ decomposes in two steps and no intermediate product of the composition $\mathrm{SrF}_{2} \cdot \mathrm{HF}$ is formed:

$$
\mathrm{SrF}_{2} \cdot 2 \cdot 5 \mathrm{HF} \underset{82^{\circ}}{\stackrel{-0.5 \mathrm{HF}}{\longrightarrow}} \mathrm{SrF}_{2} \cdot 2 \mathrm{HF} \stackrel{-2 \mathrm{HF}}{145^{\circ}} \mathrm{SrF}_{2} \text {. }
$$

Similarly to $\mathrm{SrF}_{2} \cdot 2 \mathrm{HF}, \mathrm{CaF}_{2} \cdot 2 \mathrm{HF}$ is characterized by simultaneous splitoff of two $\mathrm{HF}$ molecules. $\mathrm{SrF}_{2} \cdot \mathrm{HF}$ is less stable than $\mathrm{BaF}_{2} \cdot \mathrm{HF}$ and decomposes at a lower temperature $\left(\sim 100^{\circ}\right)$.

Thermogravimetric data indicate that, as a result of their stepwise decompositions, higher barium and strontium hydrofluorides may be used for the synthesis of hydrofluorides that are intermediates in these decompositions. This type of synthesis is particularly well-suited for compounds having narrow crystallization ranges in ternary systems.

We have calculated the kinetic parameters of the non-isothermal decompositions of the alkaline earth hydrofluorides (Table 7).

The thermal stabilities of the alkaline earth metal hydrofluorides increase from calcium to barium, i.e. with cation radius, similarly to the alkali metal hydrofluorides.

The applicability of hydrofluorides as fluorinating agents for various classes of substances deserves mention. In many cases, hydrofluorides may successfully 
Table 7

Kinetic parameters of alkaline earth metal hydrofluoride decomposition processes under non-isothermal conditions

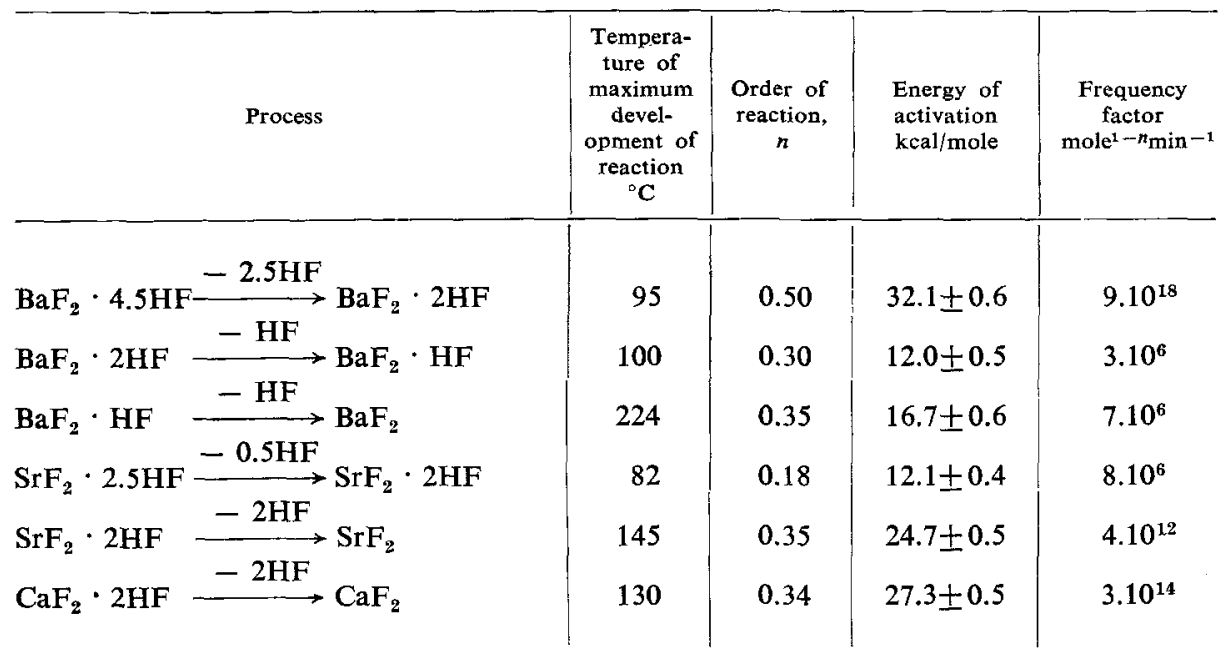

be applied instead of hydrofluoric acid, which involves difficulties in the experimental work. For such purposes, mainly sodium, potassium and ammonium bifluorides are used. As compared to alkali metal bifluorides, $\mathrm{NH}_{4} \mathrm{~F} \cdot \mathrm{HF}$ has the advantage that after completion of the fluorinating reaction its excess is readily removable in the form of volatile products. The reactivity of $\mathrm{NH}_{4} \mathrm{~F} \cdot \mathrm{HF}$ is close to that of anhydrous hydrofluoric acid, while its melting point and boiling point are low and high temperatures are not required in its fluorinating reactions.

Ammonium bifluoride is capable of fluorinating various classes of substances. Fluorination of oxides yields complex ammonium salts and anhydrous fluorides [51 -64] Ammonium bifluoride has been successfully applied for the fluorination of other types of compounds [56-68].

Hydrofluorides have also been used to fluorinate a number of metals. Our studies on the interaction of alkali metal and ammonium bifluorides with aluminium and silicon indicated that fluorination proceeds at fairly low temperatures, and is accompanied by a significant thermal effect and vigorous gas evolution. The reaction between aluminium and $\mathrm{MF} \cdot \mathrm{HF}(\mathrm{M}=\mathrm{K}, \mathrm{Rb}, \mathrm{Cs})$ starts soon after melting, while in the case of ammonium bifluoride, the reaction begins practically at the melting point. Silicon reacts with bifluorides at even lower temperatures. In the sequence potassium, rubidium and caesium bifluoride a successive lowering of the temperature of reaction with metals is observed. The reaction products of aluminium and silicon with alkali metal and ammonium bifluorides are hexafluoro complexes and binary fluorides. A further decrease in the fluorination temperature of metals is obtained when higher bifluorides with lower melting points than the bifluorides are applied [69]. 
In conclusion, we wish to note that although a large number of data on the thermal properties of hydrofluorides are already available, this problem cannot be considered as fully elucidated. For many hydrofluorides, only qualitative data are known, and this hinders the conception of a full picture on these compounds. In our opinion, much work is still required in studies of dissociation pressures, kinetic and thermodynamic characteristics and mechanisms of decomposition processes. Investigations of interactions between hydrofluorides and various classes of inorganic substances are also undoubtedly of great interest.

\section{References}

1. A. A. Opalovsky and T. D. Fedotova, Hydrofluorides, Science, Novosibirsk, 1973; Usp. Khim., 39 (1970) 2097.

2. H. MoIssan, Compt. Rend., 106 (1888) 547.

3. F. M. Meyer and W. SAndow, Ber., 54 (1921) 759.

4. K. Fredenhagen and C. Cadenbach, Z. Anorg. Allgem. Chem., 178 (1929) 289.

5. F. C. Mathers and P. T. Stroup, Trans. Am. Electrochem. Soc., 66 (1934) 113.

6. R. L. Adamczak, J. A. Mattern and H. Tieckelmann, J. Phys. Chem. 63 (1959) 2063.

7. G. H. CaDY, J. Am. Chem. Soc., 56 (1934) 1431.

8. K. R. Webi and A. B. R. Prideaux, J. Chem. Soc., (1939) 111.

9. R. V. WInsor and J. H. CADY, J. Am. Chem. Soc., 70 (1948) 1500.

10. O. Ruff and L. Staur, Z. Anorg. Allgem. Chem., 212 (1933) 399.

11. R. D. Euler and E. F. Westrum, J. Phys. Chem., 65 (1961) 1291.

12. B. N. Sudarikov, V. A. Cherkasov, E. G. Rakov and B. V. Gromov, Trudy Mosk. Khim. Tekhnol. Inst., No. 58 (1968) 33.

13. I. A. Semerikova and A. F. Alabyshev, Zh. Fiz. Khim., 35 (1961) 2791; 36 (1962) 1070 .

14. W. C. Schumb, B. Jong and K. Radimer, Ind. Eng. Chem., 39 (1947) 244.

15. S. E. Wheartry, J. Phys. Chem., 35 (1931) 3187.

16. I. A. Semerikova and A. F. Alabyshev, Zh. Fiz. Khim., 37 (1963) 207; 36 (1962) 2774.

17. A. F. Alabyshev, I. A. Semerikova, Yu. I. Yusova and E. V. Kurbatova, Trudy II. Vses. Simp. po neorg. ftoridam, Moscow, 1970, p. 202.

18. I. A. Semerikova and A. F. Alabyshev, Zh. Fiz. Khim., 36 (1962) 1341.

19. B. N. Sudarikov, V. A. Cherkasov, E. G. Rakov and V. D. Bratishko, Trudy Mosk. Khim. Tekhnol Inst., No. 58 (1968) 37.

20. I. V. Tananaev, Khim. Redkikh Elementov Akad. Nauk SSSR Inst. Obshch.; Neorgan. Khim., No. 1 (1954) 33.

21. E. F. Westrum, and G. A. Burney, J. Phys. Chem., 65 (1961) 344.

22. J. D. Cox and D. HARrop, Trans. Faraday, Soc., 61 (1965) 1328.

23. A. R. Miller, J. Phys. Chem., 71 (1967) 1144.

24. A. P. Belova and Yu. D. Nekrasov, Zh. Neorg. Khim., 11 (1966) 1723.

25. J. F. Froning, M. K. Richards, T. W. Stricklin and S. G. Turnbuli, Ind. Eng. Chem., 39 (1947) 275.

26. F. A. Lenfesty, T. D. Farr and G. S. Brosher, Ind. Eng. Chem., 44 (1952) 1448.

27. J. Fischer, J. Am. Chem. Soc., 79 (1957) 6363.

28. A. A. Opalovsky, V. E. Fedorov and T. D. Fedotova, J. Thermal Anal., 2 (1970) 373.

29. A. A. Opalovsky, V. E. Fedorov and T. D. Fedotova, Proc. Third Internat. Conf. Thermal Anal., Davos, 1971.

30. H. Morgen and J. H. Hildebrand, J. Am. Chem. Soc., 48 (1925) 915.

31. E. F. Westrum and K. S. Pitzer, J. Am. Chem. Soc., 71 (1949) 1940.

32. M. Forcrand, Comp. Rend., 152 (1911) 1557. 
33. N. P. Galkin and B. A. Krutikov, Teknologiya ftora (Technology of fluorine), Atomizdat, Moscow, 1968.

34. A. A. Banks, H. J. Emelius and A. A. Woolf, J. Chem. Soc., (1949) 2861.

35. N. P. Galkin, A. A. Mayorov et al., Khimiya i tekhnologiya ftoristykh soedineny urana, (Chemistry and technology of uranium fluoro compounds.) Gosatomizdat, Moscow, 1961.

36. R. C. Dowing, In Preparation, properties and technology of fluorine and organic fluoro compounds, New York, 1951.

37. Yu. I. Yusova and A. F. Alabyshev, Zh. Fiz. Khim., 36 (1962) 2772.

38. Yu. I. Yusova and A. F. Alabyshev, Zh. Fiz. Khim., 37 (1963) 449.

39. T. L. Higgins and E. F. Westrum, J. Phys. Chem., 65 (1961) 830.

40. I. V. Tananaev, Zh. Obshch. Khim., 11 (1941) 270.

41. I. V. Tananaev, Zh. Prikl. Khim., 11 (1938) 214.

42. J. Meyer and W. Taube, Z. Anorg. Allgem. Chem., 27 (1936) 337.

43. L. ERDey, S. GÁl and G. Liptay, Talanta, 11 (1964) 913.

44. V. S. Yatlov and E. M. Polyakova, Zh. Obshch. Khim., 15 (1945) 724.

45. Yu. I. Yusova and A. F. Alabyshev, Zh. Fiz. Khim., 37 (1963) 1870.

46. E. Benjamins, Dissertation Abstr., 15 (1955) 715.

47. H. Schultza, M. Eucken and W. Naemsch, Z. Anorg. Aligem. Chem., 292 (1957) 293.

48. B. N. Sudarikov, V. A. Cherkasov, E. G. Rakov and V. D. Bratishko, Trudy Mosk. Khim. Tekhnol. Inst. No. 56 (1967) 228.

49. A. A. Opalovsky, V. E. Fedorov and T. D. Fedotova, J. Thermal Anal., 1 (1969) 301.

50. A. A. Opalovsky, V. E. Fedorov, T. D., Fedotova and N. I. Tyuleneva, Trudy II. Vses. Simp. po neorg. ftoridam, Moscow, 1970, p. 41.

51. Preparative inorganic reactions, Ed. W. L. Jolly. Interscience Publ., New York, London, Sydney, 1965.

52. R. Thoma, C. Weaver, H. Fredman, H. Insley, L. Harris and H. Yakel, J. Phys. Chem., 65 (1961) 1096.

53. R. Thoma, H. InSley and G. Hebert, Inorg. Chem., 5 (1966) 1222.

54. D. R. Batsanova, Usp. Khim., 40 (1971) 945.

55. M. TAYloR, Chem. Rev., 62 (1962) 503.

56. M. TAYlor and C. Carter, J. Inorg. Nucl. Chem., 24 (1962) 387.

57. J.-P. Besse and M. Capestan, Bull. Soc. Chim. France (1966) 577.

58. C. Decroly, G. Tutgat and J. Gerard, Energie Nucl., 1 (1957) 155.

59. B. Gaudreau, Comp. Rend., C263 (1966) 67.

60. Ya. Maly, I. Peka and M. Talash, Radiokhimiya, 3 (1961) 1965.

61. L. Neumann, M. Maucha and S. Podesva, Collection Czech. Chem. Commun., 27 (1962) 472.

62. L. K. Marinina, E. G. Rakov, V. D. Bratishko, B. V. Gromov and S. A. Kokanov, Zh. Neorgan. Khim., 16 (1970) 3279.

63. W. Fringeli, E. Glass and H. Erlenmeyer, Chimia Arau, 22 (1968) 186.

64. I. G. RYss and I. Y. TulchinskY, Zh. Neorg. Khim., 7 (1962) 1313.

65. J. NiEMEC, Comp. Rend., 251 (1960) 875.

66. N. Ya. Turova, A. V. Novoselova and K. N. Semenenko, Zh. Neorg. Khim., 1 (1956) 2567.

67. A. RaY and G. Mitra, J. Indian Chem. Soc., 35 (1958) 677.

68. L. K. Marinina, E. G. Rakov, B. V. Gromov, V. A. Minaev and S. A. Kokanov, Trudy Mosk. Khim. Tekhnol. Insı., No. 67 (1970) 87.

69. A. A. Opalovsky, V. E. Fedorov and T. D. Fedotova, J. Thermal Ana1., 5 (1972) 475. 
RÉsumÉ - On présente les données se rapportant aux propriétés thermiques des hydrofluorures des métaux alcalins et alcalino-terreux. La fusion, la décomposition thermique et l'interaction des hydrofluorures avec différents groupes de substances inorganiques sont discutées. On montre qu'il existe une certaine régularité dans l'évolution des propriétés thermiques à l'intérieur de la séquence des hydrofluorures mentionnés ci-dessus. On présente la direction future des recherches dans ce domaine.

ZuSAMmenfassung - Angaben über die thermischen Eigenschaften von Alkali und Erdalkali-hydrofluoriden werden bekanntgegeben. Schmelzen, thermische Zersetzung und Reaktion von Hydrofluoriden mit verschiedenen Gruppen anorganischer Substanzen werden erörtert. Einige Regelmäßigkeiten der Änderungen der thermischen Eigenschaften innerhalb der Sequenzen obiger Hydrofluoride werden festgestellt. Umrisse der zukünftigen Richtlinien für die Forschungsarbeit auf diesem Gebiete werden gegeben.

Резюме - В работе представлены данные по термическим свойствам гидрофторидов щелочных и щелочно-земельных металлов. Рассмотрены процессы плавления, термического разложения и взаимодействия гидрофторидов с различными классами неорганических веществ. Установлены некоторые закономерности изменения термических свойств в ряду указанных гидрофторидов. Определены перспективы дальнейшего развития исследований в этой области. 